\title{
Measurement of Basal Serum Calcitonin for the Diagnosis of Medullary Thyroid Cancer
}

\section{Authors}

Stephanie Allelein ${ }^{1}{ }^{*}$, Margret Ehlers ${ }^{1}{ }^{*}$, Corinna Morneau ${ }^{1}$, Katharina Schwartz ${ }^{2}$, Peter E. Goretzki ${ }^{2}$, Thomas Seppel ${ }^{3}$, Joachim Feldkamp ${ }^{4}$, Andreas Krieg ${ }^{5}$, Wolfram Trudo Knoefel ${ }^{5}$, Anne Kuebart ${ }^{1}$, Matthias Haase ${ }^{1}$, Till Dringenberg ${ }^{1}$, Christine Schmid ${ }^{1}$, Matthias Schott ${ }^{1}$

\section{Affiliations}

1 Division for Specific Endocrinology, Medical Faculty, University Hospital Duesseldorf, Duesseldorf, Germany

2 Department of Surgery, Lukas Hospital, Neuss, Germany

3 Outpatient Clinic for Endocrinology, Moenchengladbach, Germany

4 Department for Endocrinology and Diabetes, Municipal Hospital Bielefeld, Bielefeld, Germany

5 Department of General, Visceral and Pediatric Surgery, Medical Faculty, University Hospital Duesseldorf, Duesseldorf, Germany

Key words

c cell hyperplasia, threshold, diagnosis

received 14.08.2017

accepted 24.10.2017

\section{Bibliography}

DOI https://doi.org/10.1055/s-0043-122237

Published online: 23.11.2017

Horm Metab Res 2018; 50: 23-28

(c) Georg Thieme Verlag KG Stuttgart · New York

ISSN 0018-5043

Correspondence

Dr. Stephanie Allelein, MD, PhD

Division for Specific Endocrinology, Medical Faculty

University of Duesseldorf

Moorenstr. 5

40225 Duesseldorf

Germany

Tel.: +49/211/81 04860, Fax: +49/211/81 16443

Stephanie.Allelein@med.uni-duesseldorf.de

\section{ABSTRACT}

Calcitonin (CT), a tumor marker for medullary thyroid cancer (MTC), can be stimulated with pentagastrin or calcium. Because of the unavailability of pentagastrin, basal CT measurement is frequently used for the preoperative diagnosis of MTC. The aim of the study was to define basal serum calcitonin (bCT) cut-off thresholds for diagnosing MTC. Within a retrospective analysis, 114 patients (51 males) were included fulfilling the criteria of an increased preoperative bCT level $(>10 \mathrm{pg} / \mathrm{ml})$ and the criteria of an available postoperative histology analysis. Based on a ROC plot analysis, the cut-off values for the diagnosis of MTC vs. non-malignancy (C cell hyperplasia and goiter) were identified. The most precise bCT thresholds for the identification of MTC were $\geq 46 \mathrm{pg} / \mathrm{ml}$ for males (sensitivity: $93.6 \%$, specificity: $95.0 \%$, PPV: $97 \%$, NPV: $90 \%$ ) and $\geq 35 \mathrm{pg} / \mathrm{ml}$ for females (sensitivity: $87.3 \%$, specificity: $87.5 \%$, PPV: $98 \%$, NPV: $50 \%$ ). Using these cut-offs, only $6 \%$ of male patients were not identified of having MTC, whereas $5 \%$ were false positive (having instead C cell hyperplasia). In females, the discrepancy was higher since $13 \%$ of female MTC patients were false negative by using the cut-off of $\geq 35 \mathrm{pg} / \mathrm{ml}$, and $13 \%$ had false positive results (suffering from $C$ cell hyperplasia). Gender-specific bCT cut-offs for the identification of MTC vs. C cell hyperplasia and non-malignancy were defined, which can be used in clinical routine. In female patients, however, the accuracy is much lower compared to males.

\section{Introduction}

Calcitonin (CT), a polypeptide hormone consisting of 32 amino acids, is the major tumor marker for medullary thyroid carcinoma (MTC). CT is mainly produced and rapidly secreted into the blood not only by the thyroidal calcium-sensitive parafollicular $C$ cells but

* Both authors contributed equally to this work also by the C cell-derived MTC [1-3]. MTC itself may either occur sporadically (75\% of the cases) or as part of a familial syndrome named multiple endocrine neoplasia (MEN 2) due to an activating mutation in the RET oncogene [4,5]. MTC represents an aggressive malignancy with a 10 -year survival rate of $40-50 \%$ [6, 7]. Once distant disease occurs, treatment options are limited, and conventional cancer treatments such as cytotoxic chemotherapy are of minimal benefit [8]. 
Basal serum CT (bCT) is commonly used to diagnose and to follow-up MTC patients as its serum concentration is directly related to the $C$ cell mass $[9,10]$. It can be measured by different commercially available assays $[11,12]$. bCT's doubling time - together with carcinoembryonic antigen (CEA) doubling time - is currently considered to represent a strong prognostic indicator for MTC recurrence and death [13]. Additionally, bCT is used as a biochemical screening tool for MTC in relatives with RET mutations, including those where prophylactic and therapeutic thyroidectomy is considered [14]. Furthermore, the American Thyroid Association recommends the measurement of CT levels in the washout of fine-needle aspiration (FNA) biopsies for thyroid nodules with (i) histologically inconclusive results or (ii) features suggestive of MTC $[9,15]$.

Depending on the assay used, $56-88 \%$ of subjects without thyroid disease usually show a CT level below the functional sensitivity, while 3-10\% have CT levels greater than $10 \mathrm{pg} / \mathrm{ml}[14,16]$. ACT stimulation test using pentagastrin or calcium should be performed (i) to differentiate MTC from $\mathrm{C}$ cell hyperplasia $(\mathrm{CCH})$ to avoid unnecessary thyroidectomies; (ii) for patients with normal or slightly elevated basal CT findings and clinically suspected MTC; and (iii) possibly for screening for MTC in RET mutation-carrying relatives. The benefit of the pentagastrin-stimulation test is its higher sensitivity to detect C-cell disease compared to measurement of bCT [17]. Nevertheless, pentagastrin is not available any longer. An alternative method represents the calcium stimulation test, being described as sensitive as well, however, also having side effects $[18,19]$. Nevertheless, due to the (partly life-threatening) adverse effects [20-22] of this stimulation test and due to the not yet well defined cut-offs for the calcium stimulation test $[20,23,24]$, bCT levels are gaining in importance.

Therefore, the aim of the present work was to determine by analyzing a large series of patients cut-off values of basal (non-stimulated) bCT to diagnose MTC and to distinguish it from non-malignancies.

\section{Patients and Methods}

\section{Patients}

Within this retrospective analysis in total, 114 patients with bCT levels $>10 \mathrm{pg} / \mathrm{ml}$ were identified at four different endocrine centers in Germany between January 2008 and April 2016. All patients underwent surgery; postoperative histology results were available. We included patients with bCT levels above $10 \mathrm{pg} / \mathrm{ml}$ even though a higher limit of $15 \mathrm{pg} / \mathrm{ml}$ was discussed in another study to reduce false-positive cases [25]. By using this cut-off the chance of missing patients with very small MTCs could have been minimized [26, 27].

Sixty-three patients were females (age $63 \pm 15$ years) and 51 were males (age $64 \pm 12$ years). 86 patients had MTCs ( $n=31$ men), 23 patients had $\mathrm{CCH}(\mathrm{n}=15$ men) and 5 male patients had goiter without additional malignancy. Patients with genetically identified familial MTC or MEN 2, respectively, including those who received prophylactic thyroidectomy were excluded from the analysis. In all patients, total thyroidectomy was performed and a professional examination of the removed tissue was done by experienced pathologists. According to previously published criteria $\mathrm{CCH}$ was de- fined as 50 or more cytologically bland intrafollicular calcitonin positive cells in at least one low power field (100X) [28]. The study has been approved by the Local Ethical Committee of the Heinrich-Heine-University Duesseldorf (No. 5625).

\section{Calcitonin measurement}

Altogether, four different assays based on three assay types were used for calcitonin measurement. Each assay has its specific gender-dependent cut-off value for positivity. The following assays were used (cut-off value for positivity for women and men): Calcitonin ELISA, IBL International ( $\geq 13 \mathrm{pg} / \mathrm{ml}$; $\geq 30 \mathrm{pg} / \mathrm{ml}$ ); Calcitonin IRMA, Euroimmune ( $\geq 8 \mathrm{pg} / \mathrm{ml} ; \geq 21 \mathrm{pg} / \mathrm{ml}$ ); SELco Calcitonin IRMA, MEDIPAN ( $\geq 10 \mathrm{pg} / \mathrm{ml} ; \geq 15 \mathrm{pg} / \mathrm{ml}$ ); Calcitonin chemiluminescence assay, Siemens ( $\geq 11.5 \mathrm{pg} / \mathrm{ml} ; \geq 18.2 \mathrm{pg} / \mathrm{ml}$ ).

\section{Statistical analyses}

The CT levels are reported as single values. In order to obtain the optimal decision threshold level for positivity, receiver-operating characteristic (ROC) analysis was performed [29]. Sensitivity/Specificity pairs were calculated by varying the decision threshold levels over the entire range of CT values. Sensitivity (the true positive results) was calculated from patients with MTC. Specificity (the true negative results) was calculated from patients without malignancy and $\mathrm{CCH}$.

The positive predictive value (PPV) was calculated as follows: PPV = number of test true positive MTC patients as a fraction of the total number of test positive subjects (true and false positive subjects). The negative predictive value (NPV) was calculated as follows: NPV = number of true test negative non-MTC patients as a fraction of the total number of test negative subjects (true and false negative subjects). Comparison was done by Kruskal-Wallis test and Dunn's multiple comparison test (not normally distributed data) and calculated using Prism computer software (GraphPad Software Inc., San Diego, CA). A p-value less than 0.05 was considered statistically significant.

\section{Results}

\section{Serum calcitonin levels in patients with MTC, $\mathrm{CCH}$, and non-malignancy}

Serum CT levels are given in $>$ Fig. 1. As expected, in males as well as in females, significantly higher bCT levels were seen in MTC patients in comparison to CCH patients (male: $2173 \pm 5352 \mathrm{pg} / \mathrm{ml}$ vs. $25.0 \pm 11.0 \mathrm{pg} / \mathrm{ml}, \mathrm{p}<0.0001$; female: $1574 \pm 5826 \mathrm{pg} / \mathrm{ml}$ vs. $34.8 \pm 52.0 \mathrm{pg} / \mathrm{ml}$ ). Male MTC patients also showed significantly higher bCT levels in comparison to goiter patients without malignancy and $\mathrm{CCH}(22 \pm 12.8 \mathrm{pg} / \mathrm{ml}, \mathrm{p}<0.0001)$.

Gender-specific significant differences were neither seen for $\mathrm{CCH}$ nor for MTC patients (comparing the mean values). Of note, however, detailed analyses of moderately increased CT levels revealed gender-dependent differences: Investigating non-MTC patients with bCT levels below $34 \mathrm{pg} / \mathrm{ml}$ significant differences could be identified (men: $20.6 \pm 7.0$ and women: $13.6 \pm 3.4 \mathrm{pg} / \mathrm{ml}$, $p=0.023$ ). A similar picture was seen for bCT levels $\leq 200 \mathrm{pg} / \mathrm{ml}$. Here, significantly higher CT levels were seen for male patients compared to females (men: $108.1 \pm 61.5$ and women: 
$67.5 \pm 47.3 \mathrm{pg} / \mathrm{ml}, \mathrm{p}=0.046)$. This data, as well as the fact that men thyroids harbor twice more C-cells than women's [30], indicate the necessity to consider male and female CT levels individually.

\section{Cut-off definition for the diagnosis of medullary thyroid cancer}

In order to calculate gender-specific CT thresholds, ROC plot analyses were performed ( $>$ Fig. 2). Sensitivity and specificity were calculated in order to differentiate non-MTC (control and CCH) from MTC in men as well as in women. The areas under the curve (AUC) were as follows: 0.9661 (95\% Cl: 0.9175-1.015), $\mathrm{p}<0.0001$ for men; and 0.9364 (95\% Cl: 0.8473-1.025), $\mathrm{p}<0.0001$ for women ( $\triangleright$ Fig. 2). In male patients, optimal sensitivity (93.6\%) and specificity $(95.0 \%$ ) were seen at a cut-off of $\geq 46 \mathrm{pg} / \mathrm{ml}$ to distinguish the non-MTC group from the MTC group. The corresponding PPV was $97 \%$, whereas the NPV was estimated to be $90 \%$ ( Fig. 2). In females, optimal sensitivity (87.3\%) and specificity (87.5\%), with a PPV of $98 \%$ and a NPV of $50 \%$, were seen at a cut-off level of $\geq 35 \mathrm{pg} / \mathrm{ml}$ ( $>$ Fig. 2 ).

In addition, we also analyzed CT levels, which were under the defined cut-offs. Here, in the group of male patients with CT levels below $30 \mathrm{pg} / \mathrm{ml} 2$ patients had MTC $(2 / 31 ; 6 \%)$ resulting in a sensitivity of $93.6 \%$ and a specificity of $75.0 \%$. The corresponding PPV and NPV were $85 \%$ and $88 \%$. Below $20 \mathrm{pg} / \mathrm{ml}$ only 1 patient suffered from MTC $(1 / 31 ; 3 \%)$. Using this cut-off, a sensitivity of $96.8 \%$, a specificity of $40.0 \%$, a PPV of $71 \%$, and a NPV of $89 \%$ were reached. Similarly, in the group of female patients with CT levels below $30 \mathrm{pg} / \mathrm{ml} 5$ patients had MTC (5/55; $9 \%$; sensitivity: $90.9 \%$; specificity: 75.0\%; PPV: 96\%; NPV: $55 \%$ ). Below a threshold of $20 \mathrm{pg} / \mathrm{ml} 2$ patients suffered from MTC (2/55; $4 \%$; Sens: $96.4 \%$; Spez.: 75.0\%; PPV 96\%, NPV 75\%).

\section{Discussion}

The aim of the present study was to identify the most accurate basal CT (bCT) cut-off for the preoperative identification of patients with medullary thyroid cancer (MTC). Based on ROC curve analyses we identified cut-offs to distinguish non-MTC patients (including goiter patients without signs of malignancy and $C$ cell hyperplasia, respectively) from MTC patients. In females, a cut-off of $\geq 35 \mathrm{pg} / \mathrm{ml}$ was identified whereas in males the cut-off was $\geq 46 \mathrm{pg} / \mathrm{ml}$ for diagnosing MTC. According to previous data, we also saw a significant correlation of $\mathrm{bCT}$ with tumor size for men and women (data not shown) as well as an association of bCT level and lymph node metastasis (data not shown) [31,32].

Due to the gender dependent differences in lower bCT levels and due to the fact man having a larger $\mathrm{C}$-cell mass than women [30], we calculated ROC analysis for male and female patients separately. In our analysis, only 2 female patients and 1 male patient with bCT $\geq 35 \mathrm{pg} / \mathrm{ml}$ or $\geq 46 \mathrm{pg} / \mathrm{ml}$, respectively, did not have MTC. In these patients, however, a CCH was detected. Therefore, patients with bCT levels above the defined gender-restricted cut-offs have to be informed about the rare chance of not having a MTC (female: $13 \%$; male: $6 \%$ ). On the other hand, there were 7 female MTC patients and 2 male MTC patients who would have been missed by using the defined thresholds. Therefore, patients with CT levels below the calculated cut-off have to be informed about a $25 \%$

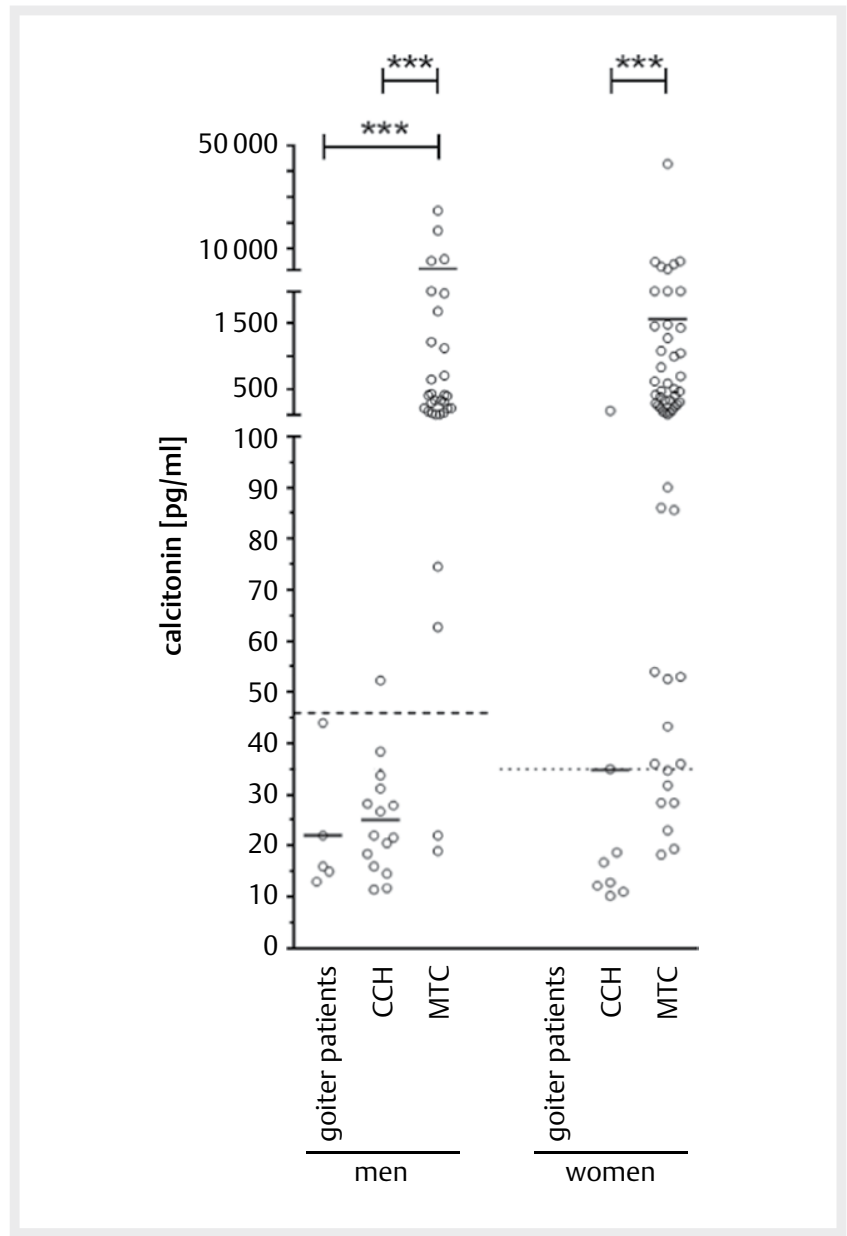

Fig. 1 Distribution of CT in male and female goiter, $\mathrm{CCH}$, and MTC subjects; $\mathrm{CT}$ levels of male and female patients suffering from goiter, $C$ cell hyperplasia (CCH), and medullary thyroid cancer (MTC): The gender-specific distribution of serum $\mathrm{CT}$ levels of goiter patients, CCH patients, and MTC patients is shown. The calculated cut-offs (men: $46 \mathrm{pg} / \mathrm{ml}$; women: $35 \mathrm{pg} / \mathrm{ml}$ ) are indicated (dashed lines). One male non-MTC patient was above and two male MTC patients were below the calculated cut-off. For females, two non-MTC patients showed CT levels above and 7 MTC patients showed CT levels below the calculated cut-off.

chance in females and $5 \%$ chance in males, respectively, of having MTCs, as well. Of note, taking the lowest CT-level being measured in MTC would result in very low specificities (men: $40 \%$ and women: $62.5 \%$ ), leading - at least for male patients - to a multitude of unneeded surgical interventions (men: $23.5 \%$ and women: $4.8 \%$ of all patients).

Irrespectively, one has to keep in mind, that falsely negative of positive bCT values, respectively, can be obtained due to influencing factors such as heterophilic antibodies, drugs, hook effect etc. $[33,34]$ as well as disease related pathological conditions, for example, renal failure, neuroendocrine tumors of the lung or gastrointestinal tract, or sepsis $[27,35,36]$. In order to reduce the impact of genetic factors we excluded genetically identified familial MTC or MEN 2, respectively, and patients with additional tumor diseases. It has also to be mentioned that cut-off calculations in our study was based on single CT measurements. Therefore, we cannot ex- 
a

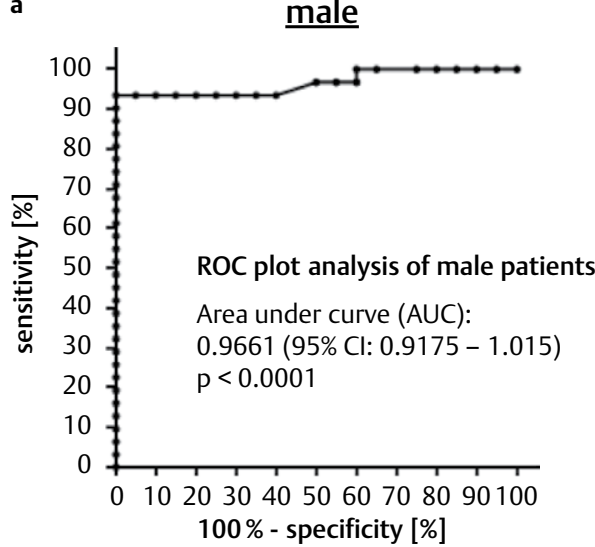

c

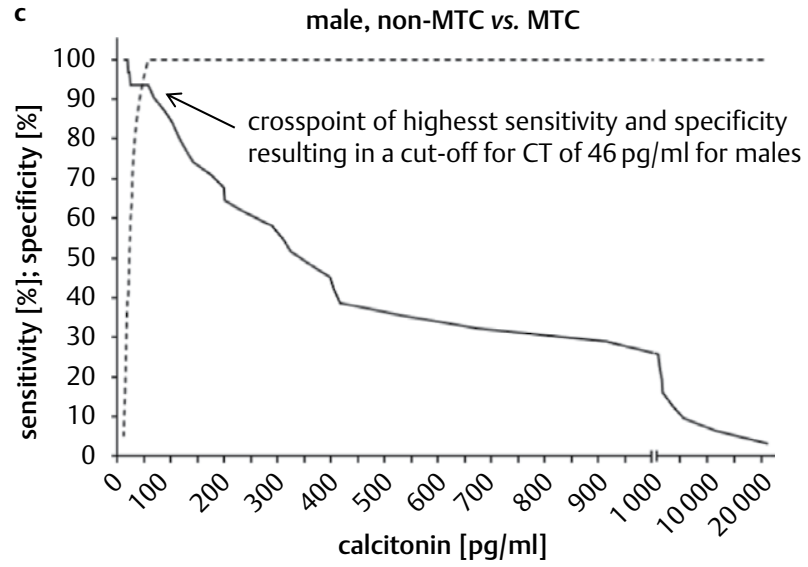

b female

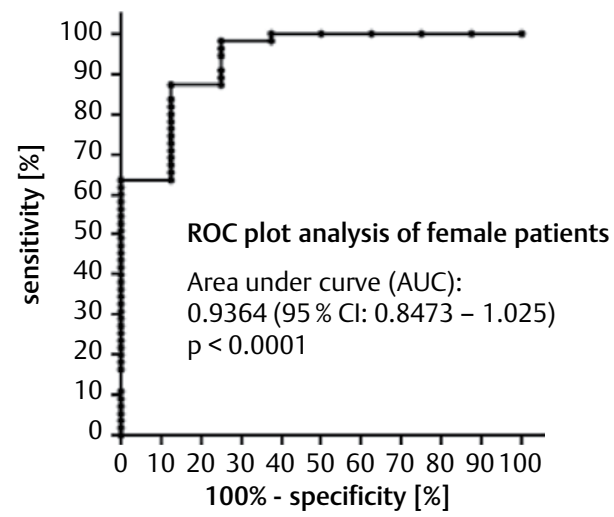

d

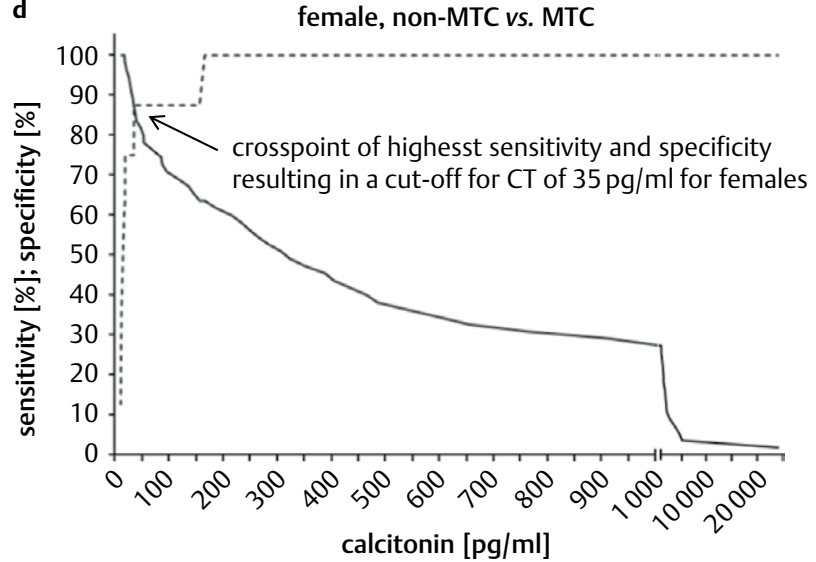

- Fig. 2 Cut-offs for serum CT levels (non-MTC vs. MTC); ROC plot analysis and determination of CT cut-off for male and female patients: ROC plot analysis including the data of patients with MTC for sensitivity and non-MTC subjects including goiter patients without malignancy and patients suffering from CCH for specificity is shown for males a and females c. Based on these data the calculated sensitivity (solid line) and specificity (dashed line) is shown for males $\mathbf{b}$ and females $\mathbf{d}$. The cross-point of both lines represents the calculated cut-off for CT with highest sensitivity and specificity.

clude that additional CT measurements might have led to slightly different results.

Most data in the past have shown that the positive predictive value of measuring basal CT for the diagnosis of MTC is lower than for stimulated CT [19]. In contrast, Mian et al. [23] indicated that bCT values are at least as good predictors for MTC as stimulated CT values and suggested that bCT assays with improved functional sensitivity may avoid the stimulation test in several conditions. Our data with a larger cohort of patients revealed almost identical results for the diagnosis of MTC compared to previously published data with less patient numbers [23] even though in our study the specificity was not as high as previously published (of note, the AUC were similar). Another study by Chambon et al. reported the detection of i) MTCs in $26 \%$ of patients and ii) $\mathrm{CCH}$ in $76 \%$ of patients with bCT levels $>10 \mathrm{pg} / \mathrm{ml}$ [26]. Within this study - with only 43 patients with elevated CT levels - no threshold for the detection of MTC was, however, calculated as we did. Taken together, the possibility of relying only on bCT would definitely increase the cost-effectiveness of the measurement of $\mathrm{CT}$ and the practicability in diagnosing MTC.
Our study also has some limitations. One drawback is the use of different assays. Within our retrospective analysis, altogether four different calcitonin assays have been used for testing. Each of these assays have gender-specific cut-offs for positivity ranging from 8 to $13 \mathrm{ng} / \mathrm{ml}$ for females and 15 to $30 \mathrm{ng} / \mathrm{ml}$ for males. In the past, however, it has already been demonstrated that interassay variabilities of these assays are quite low $(<10 \%$ for CT concentrations higher than $10 \mathrm{pg} / \mathrm{ml}$ ) [16]. Although the definition of an assay-independent cutoff being questionable [12] our thresholds for bCT ( $\geq 46 \mathrm{ng} / \mathrm{ml}$ for males and $\geq 35 \mathrm{ng} / \mathrm{ml}$ for females) are comparable to those found in other assay-dependent reports (males: $\geq 68 \mathrm{ng} / \mathrm{ml}$ and $\geq 32.8 \mathrm{ng} / \mathrm{ml}$; females $\geq 26 \mathrm{ng} / \mathrm{ml}, 18.7 \mathrm{ng} / \mathrm{ml}$, and $\geq 14.6 \mathrm{ng} / \mathrm{ml}$ ) $[20,23]$ indicating an advantage of our data: our results can be applied to different assay types for CT determination, at least for the assays used in our study.

Further limitations of our study are the missing data regarding the use of for instance proton pump inhibitors (PPIs) that have been described to increase $C T$ concentrations $[12,37]$. Besides, no data were available regarding the handling of the sample (from the time point of blood sampling till CT measurement), the age and weight 
of patient or cigarette smoking. Although all these factors (including the use of a single test optimally) were not taken into account, the calculated cut-offs were - as mentioned above - similar to previous studies [16, 23].

A further drawback of our study is the absence of female goiter patients. The relatively low number of female $\mathrm{CCH}$ subjects (with one female having an extremely high bCT level) and the missing female controls might explain the relatively high cut-off ( $\geq 35 \mathrm{ng} / \mathrm{ml}$, in comparison to $\geq 26$ or $\geq 18.7 \mathrm{ng} / \mathrm{ml}$ as previously reported) $[20,23]$ and the poor specificity for females in our study.

In summary, we have identified gender-specific thresholds for the preoperative diagnosis of MTC, which can be used in clinical routine with reliable sensitivities and specificities. The data are comparable with previously published data. Additional studies are certainly required in order to confirm our data. These studies should also include double calcitonin measurements and a postoperative follow-up analyses. Still, until data with larger patient cohorts are available, we recommend the identified cut-offs for preoperative diagnostics and the indication of surgery.

\section{Acknowledgements}

We thank Roswitha Charko and Ursula Doetter for excellent technical assistance.

\section{Conflict of Interest}

The authors declare that they have no conflict of interest.

\section{References}

[1] Camacho CP, Lindsey SC, Melo MC, Yang JH, Germano-Neto F, Valente Fde O, Lima TR, Biscolla RP, Vieira JG, Cerutti JM, Dias-da-Silva MR, Maciel RM. Measurement of calcitonin and calcitonin gene-related peptide mRNA refines the management of patients with medullary thyroid cancer and may replace calcitonin-stimulation tests. Thyroid 2013; 23: 308-316

[2] Jackson CE, Tashjian AH Jr., Block MA. Detection of medullary thyroid cancer by calcitonin assay in families. Ann Intern Med 1973; 78 : 845-852

[3] McMillan P], Hooker WM, Deptos L]. Distribution of calcitonin-containing cells in the human thyroid. Am J Anat 1974; 140: 73-79

[4] Carlson KM, Dou S, Chi D, Scavarda N, Toshima K, Jackson CE, Wells SA Jr., Goodfellow PJ, Donis-Keller H. Single missense mutation in the tyrosine kinase catalytic domain of the RET protooncogene is associated with multiple endocrine neoplasia type 2B. Proc Natl Acad Sci U S A 1994; 91: 1579-1583

[5] Donis-Keller H, Dou S, Chi D, Carlson KM, Toshima K, Lairmore TC, Howe JR, Moley JF, Goodfellow P, Wells SA Jr.. Mutations in the RET proto-oncogene are associated with MEN $2 \mathrm{~A}$ and FMTC. Hum Mol Genet 1993; 2: 851-856

[6] Modigliani E, Cohen R, Campos JM, Conte-Devolx B, Maes B, Boneu A, Schlumberger M, Bigorgne JC, Dumontier P, Leclerc L, Corcuff B, Guilhem I. Prognostic factors for survival and for biochemical cure in medullary thyroid carcinoma: Results in 899 patients. The GETC Study Group. Groupe d'etude des tumeurs a calcitonine. Clin Endocrinol (Oxf) 1998; 48: 265-273
[7] Schlumberger M, Carlomagno F, Baudin E, Bidart JM, Santoro M. New therapeutic approaches to treat medullary thyroid carcinoma. Nat Clin Pract Endocrinol Metab 2008; 4: 22-32

[8] Ernani V, Kumar M, Chen AY, Owonikoko TK. Systemic treatment and management approaches for medullary thyroid cancer. Cancer Treat Rev 2016; 50: 89-98

[9] Wells SA Jr., Asa SL, Dralle H, Elisei R, Evans DB, Gagel RF, Lee N, Machens A, Moley JF, Pacini F, Raue F, Frank-Raue K, Robinson B, Rosenthal MS, Santoro M, Schlumberger M, Shah M, Waguespack SG. American thyroid association guidelines task force on medullary thyroid C. Revised American Thyroid Association guidelines for the management of medullary thyroid carcinoma. Thyroid 2015; 25: 567-610

[10] Rosario PW, Calsolari MR. Usefulness of serum calcitonin in patients without a suspicious history of medullary thyroid carcinoma and with thyroid nodules without an indication for fine-needle aspiration or with benign cytology. Horm Metab Res 2016; 48: 372-276

[11] Kahaly G], Algeciras-Schimnich A, Davis TE, Diana T, Feldkamp J, Karger S, Konig J, Lupo MA, Raue F, Ringel MD, Sipos JA, Kratzsch J. United States and European multicenter prospective study for the analytical performance and clinical validation of a novel sensitive fully automated immunoassay for calcitonin. Clin Chem 2017; 63: 1489-1496

[12] Kratzsch J, Petzold A, Raue F, Reinhardt W, Brocker-Preuss M, Gorges R, Mann K, Karges W, Morgenthaler N, Luster M, Reiners C, Thiery J, Dralle $\mathrm{H}$, Fuhrer D. Basal and stimulated calcitonin and procalcitonin by various assays in patients with and without medullary thyroid cancer. Clin Chem 2011; 57: 467-474

[13] Meijer JA, le Cessie S, van den Hout WB, Kievit J, Schoones JW, Romijn JA, Smit JW. Calcitonin and carcinoembryonic antigen doubling times as prognostic factors in medullary thyroid carcinoma: a structured meta-analysis. Clin Endocrinol (Oxf) 2010; 72: 534-542

[14] American Thyroid Association Guidelines Task F.Kloos RT, Eng C, Evans DB, Francis GL, Gagel RF, Gharib H, Moley JF, Pacini F, Ringel MD, Schlumberger M, Wells SA Jr. Medullary thyroid cancer: management guidelines of the American Thyroid Association. Thyroid 2009; 19: 565-612

[15] Trimboli P, Cremonini N, Ceriani L, Saggiorato E, Guidobaldi L, Romanelli F, Ventura C, Laurenti O, Messuti I, Solaroli E, Madaio R, Bongiovanni M, Orlandi F, Crescenzi A, Valabrega S, Giovanella L. Calcitonin measurement in aspiration needle washout fluids has higher sensitivity than cytology in detecting medullary thyroid cancer: a retrospective multicentre study. Clin Endocrinol (Oxf) 2014; 80: $135-140$

[16] d'Herbomez M, Caron P, Bauters C, Do Cao C, Schlienger JL, Sapin R, Baldet L, Carnaille B, Wemeau JL.French Group GTE. Reference range of serum calcitonin levels in humans: Influence of calcitonin assays, sex, age, and cigarette smoking. Eur J Endocrinol 2007; 157: 749-755

[17] Pina G, Dubois S, Murat A, Berger N, Niccoli P, Peix JL, Cohen R, Guillausseau C, Charrie A, Chabre O, Cornu C, Borson-Chazot F, Rohmer V.Groupe des Tumeurs E. Is basal ultrasensitive measurement of calcitonin capable of substituting for the pentagastrin-stimulation test? Clin Endocrinol (Oxf) 2013; 78: 358-364

[18] Daumerie C, Maiter D, Gruson D. Serum calcitonin estimation in medullary thyroid cancer: Basal or stimulated levels? Thyroid Res 2013; 6: (Suppl 1): S4

[19] Verburg FA, Reiners C, Grelle I, Barth H, Fassnacht M. Luster M. Calcium stimulated calcitonin measurement: A procedural proposal. Exp Clin Endocrinol Diabetes 2013; 121: 318-320

[20] Colombo C, Verga U, Mian C, Ferrero S, Perrino M, Vicentini L, Dazzi D, Opocher G, Pelizzo MR, Beck-Peccoz P, Fugazzola L. Comparison of calcium and pentagastrin tests for the diagnosis and follow-up of medullary thyroid cancer. J Clin Endocrinol Metab 2012; 97: 905-913 
[21] Doyle P, Duren C, Nerlich K, Verburg FA, Grelle I, Jahn H, Fassnacht M, Mader U, Reiners C, Luster M. Potency and tolerance of calcitonin stimulation with high-dose calcium versus pentagastrin in normal adults. J Clin Endocrinol Metab 2009; 94: 2970-2974

[22] Russo M, Scollo C, Padova G, Vigneri R, Pellegriti G. Cardiac arrest after intravenous calcium administration for calcitonin stimulation test. Thyroid 2014; 24: 606-607

[23] Mian C, Perrino M, Colombo C, Cavedon E, Pennelli G, Ferrero S, De Leo S, Sarais C, Cacciatore C, Manfredi GI, Verga U, lacobone M, De Pasquale L, Pelizzo MR, Vicentini L, Persani L, Fugazzola L. Refining calcium test for the diagnosis of medullary thyroid cancer: Cutoffs, procedures, and safety. J Clin Endocrinol Metab 2014; 99: 1656-1664

[24] Papadakis G, Keramidas I, Triantafillou E, Kanouta F, Pappa T, Kaltzidou V, Tertipi A, Iordanidou L, Trivizaki E, Vecchini G, Villiotou V, Pappas A. Association of basal and calcium-stimulated calcitonin levels with pathological findings after total thyroidectomy. Anticancer Res 2015; 35: 4251-4258

[25] Rink T, Truong PN, Schroth H], Diener J, Zimny M, Grunwald F. Calculation and validation of a plasma calcitonin limit for early detection of medullary thyroid carcinoma in nodular thyroid disease. Thyroid 2009; 19: 327-332

[26] Chambon G, Alovisetti C, Idoux-Louche C, Reynaud C, Rodier M, Guedj AM, Chapuis H, Lallemant JG, Lallemant B. The use of preoperative routine measurement of basal serum thyrocalcitonin in candidates for thyroidectomy due to nodular thyroid disorders: Results from 2733 consecutive patients. J Clin Endocrinol Metab 2011; 96: 75-81

[27] Costante G, Durante C, Francis Z, Schlumberger M, Filetti S. Determination of calcitonin levels in C-cell disease: clinical interest and potential pitfalls. Nat Clin Pract Endocrinol Metab 2009; 5: 35-44

[28] Albores-Saavedra J, Monforte H, Nadji M, Morales AR. C-cell hyperplasia in thyroid tissue adjacent to follicular cell tumors. Hum Pathol 1988; 19: 795-799
[29] Zweig MH, Campbell G. Receiver-operating characteristic (ROC) plots: a fundamental evaluation tool in clinical medicine. Clin Chem 1993; 39: $561-577$

[30] Guyetant S, Rousselet MC, Durigon M, Chappard D, Franc B, Guerin O, Saint-Andre JP. Sex-related C cell hyperplasia in the normal human thyroid: a quantitative autopsy study. J Clin Endocrinol Metab 1997; 82: $42-47$

[31] Cohen R, Campos JM, Salaun C, Heshmati HM, Kraimps JL, Proye C, Sarfati E, Henry JF, Niccoli-Sire P, Modigliani E. Preoperative calcitonin levels are predictive of tumor size and postoperative calcitonin normalization in medullary thyroid carcinoma. Groupe d'Etudes des Tumeurs a Calcitonine (GETC). J Clin Endocrinol Metab 2000; 85: 919-922

[32] Machens A, Dralle H. Biomarker-based risk stratification for previously untreated medullary thyroid cancer. J Clin Endocrinol Metab 2010; 95 : 2655-2663

[33] Bae Y], Schaab M, Kratzsch J. Calcitonin as Biomarker for the Medullary Thyroid Carcinoma. Recent Results Cancer Res 2015; 204: 117-137

[34] Tommasi M, Brocchi A, Cappellini A, Raspanti S, Mannelli M. False serum calcitonin high levels using a non-competitive two-site IRMA. J Endocrinol Invest 2001; 24: 356-360

[35] Baloch Z, Carayon P, Conte-Devolx B, Demers LM, Feldt-Rasmussen U, Henry JF, LiVosli VA, Niccoli-Sire P, John R, Ruf J, Smyth PP, Spencer CA, Stockigt JR.Guidelines Committee NAoCB. Laboratory medicine practice guidelines. Laboratory support for the diagnosis and monitoring of thyroid disease. Thyroid 2003; 13: 3-126

[36] Becker KL, Nylen ES, White JC, Muller B, Snider RH Jr.. Clinical review 167: Procalcitonin and the calcitonin gene family of peptides in inflammation, infection, and sepsis: a journey from calcitonin back to its precursors. J Clin Endocrinol Metab 2004; 89: 1512-1525

[37] Erdogan MF, Gursoy A, Kulaksizoglu M. Long-term effects of elevated gastrin levels on calcitonin secretion. J Endocrinol Invest 2006; 29: 771-775 